\title{
TTR
}

Traduction, terminologie, re?daction

\section{Perception and Cognition in Translating Chinese Landscape Poetry : A Case Study of Liu Zongyuan's poem River Snow}

\section{Chunshen Zhu}

Volume 12, numéro 1, 1er semestre 1999

Poésie, cognition, traduction I

Poetry, Cognition, Translation I

URI : https://id.erudit.org/iderudit/037358ar

DOI : https://doi.org/10.7202/037358ar

Aller au sommaire du numéro

Éditeur(s)

Association canadienne de traductologie

ISSN

0835-8443 (imprimé)

1708-2188 (numérique)

Découvrir la revue

Citer cet article

Zhu, C. (1999). Perception and Cognition in Translating Chinese Landscape

Poetry : A Case Study of Liu Zongyuan's poem River Snow. TTR, 12(1), 167-189. https://doi.org/10.7202/037358ar

\section{Résumé de l'article}

La perception et la cognition dans les traductions de la poésie chinoise du paysage : cas du poème River Snow de Liu Zongyuan - Cet article, basé sur la dichotomie heideggerienne de la pensée calculative par opposition à la pensée méditative et sur la psychologie des arts visuels de Arnheim, propose que la pensée d'un poème est celle d'un lecteur et que c'est la méditation inspirée par le poème qui détermine sa vraie nature. Par le biais de l'étude d'un poème classique chinois, nous tenterons de démontrer comment la formulation textuelle d'un poème oriente la pensée du lecteur. Ainsi pour traduire le caractère poétique d'un poème, le traducteur doit aborder le texte de départ l'esprit « vide » en se laissant imprégner par la pensée méditative offerte par le poème, c'est-à-dire en refusant la pensée calculative qui tente de représenter les objets dans leur matérialité, afin de produire un texte en langue d'arrivée qui provoquera aussi chez le lecteur une pensée méditative.
Tous droits réservés (C) TTR: traduction, terminologie, rédaction — Les auteurs, 1999
Ce document est protégé par la loi sur le droit d'auteur. L'utilisation des services d'Érudit (y compris la reproduction) est assujettie à sa politique d'utilisation que vous pouvez consulter en ligne.

https://apropos.erudit.org/fr/usagers/politique-dutilisation/ 


\section{Perception and Cognition in Translating Chinese Landscape Poetry : A Case Study of Liu Zongyuan's poem River Snow}

\section{Chunshen Zhu}

\section{Introduction}

When Su Shi (1037-1101 A. D.) remarked on one of Wang Wei's (701/698-761/759 A. D.) poems, saying "there is poetry in his painting and painting in his poetry", he was articulating, albeit unwittingly, a basic tenet of the aesthetics of classical Chinese landscape poetry and painting, to be followed by Chinese traditional intelligentsia poets artists in the centuries to come. The proposition, instead of claiming an equation between poetry and painting, as the one that has caused resentment in Lessing, asserts the relation between the two to be one of containment. That is to say, a successful painting would "contain" a poem and a successful poem a painting.

This mutual containment, to be significant for artistic creation and appreciation, is not to be understood simply at the physical or technical level. It is rather an interactive synthesis at the psychological or cognitive level, something to do with the mind, the thinking. Or in Chinese, the $y i$. The pursuit of the $y i$, in this connection, means striving for the "poetic $y i$ " in painting and the "picturesque $y i$ " in (landscape) poem writing. To incorporate the factor of viewer-reader, the relation between poetry and painting can be understood as one of inspiration a painting with the cognitive profundity of $y i$ should be able to inspire the composition of a "virtual poem" in the viewer's mind; and a poem with the same quality should be able to evoke a (series of) mental 
picture(s) in which the train of thoughts it sets free in the reader's mind can come to life. In this way if we say a landscape poem thinks, then its thinking is realized when it evokes mental pictures as "virtual paintings" in the reader's mind. And the success of its translation, in turn, lies first of all in the production of a target text that is capable of inspiring such virtual paintings in its reader's mind.

When a poem thinks, it thinks poetically. In between the Heideggerian dichotomy of meditative and calculative thinking (Heidegger, 1966), this poetic thinking belongs to meditative thinking. It differs from "scientific" calculative thinking in that it produces things as images instead of representing them as objects. By taking the form of images rather than of objects, everything in a poem demands that the reader think of them as things; that is, to try to listen and respond to the appeal of the "presencing" of their being, which "is in no way identical with reality or with a precisely determined actuality" (see Heidegger, 1971 , p. 183), when they are being brought from their remoteness into nearness to secure the being of the poem as a single time-space, a single stay of the fourfold, that is, of sky and earth, mortals and divinities. According to Heidegger, such meditative thinking

demands of us not to cling one-sidedly to a single idea, nor to run down a one-track course of ideas. [It] demands of us that we engage ourselves with what at first sight does not go together at all. (Heidegger, 1966, p. 53)

This article, from the perspective of the Heideggerian meditative thinking, seeks to give a cognitive analysis of Liu Zongyuan's poem River Snow, a poem that is generally regarded as a prime example of "word pictures" created in Chinese landscape poetry. This study is meant to illustrate the point that, to make the

\footnotetext{
${ }^{1}$ Within the Heideggerian framework of fourfold, i.e., sky, earth, mortals and divinities, the divinities 'are the beckoning messengers of the godhead', and the world is defined as the 'appropriating mirror-play' of the four, where each thing 'stays the fourfold into a happening of the simple onehood of world' (Heidegger, 1971, pp. 178, 179 and 181). Since man and the animal share the sky, earth and physical mortality, the divinity is the one that is pertinent to the spiritual domain of man's being, that renders man different from the animal 'Only man dies. The animal perishes' (p. 178) - and that, in its different varieties or 'divinities', tells human cultures from one another. In this light, it becomes essential in translating a poem to observe the 'divinity' in the world of the original text so as to preserve the mirror-play of the fourfold in the target text as 'a happening of the simple onehood of the world'.
} 
interpretation of landscape poetry more accountable for translating, an approach to poetic texts that takes into consideration both textual function and cognitive effect of the language may prove a more functional avenue than one that relies purely on an intuitive grasp seeking an epiphanic realization or technical calculations striving for a formal revelation. It will begin with a line-by-line analysis in comparison with some traditional Chinese paintings of a relevant theme, before taking the text en bloc as a virtual painting. It is at this cognitive level of virtual painting verbally evoked by the poetic text, that the English translations in Appendix 5 are examined.

The discussion as a whole tries to argue that a poem "thinks", not because the poet has been thinking, but because its textual being sets the reader thinking. By the same token, a translation of the poem "thinks", not because the poet and the translator have been thinking, similarly or differently, but because its textual being inspires the targetlanguage reader to think in a similar way.

\section{The text for analysis}

\section{Jiang Xue}

"River snow"

By Liu Zongyuan (773-819)

Qian shan niao fei jue,

"thousand mountain bird fly vanish"

Wan jing ren zong mie.

"ten-thousand footpath human trace annihilate"

Gu zhou suo li wen,

"lone boat palm-bark-cape bamboo-hat old-man"

Du diao han jiang xue.

"alone fish cold river snow"

\section{A line-by-line analysis :}

\section{Line 1}

The first word first. "Thousands of mountains" is probably one of the most clichéd words in Chinese landscape poetry. However, it has not become clichéd in the institution for nothing. The reason is not as much that it presents an impressive hyperbolic use of numerals, as conventionally believed, but rather that it conjures, in the reader's mind, wave-like outlines of the ridges which the eye would follow, 
eventually out of the frame of the mental picture, to the infinity of space. In actual painting, it is almost technically impossible and artistically undesirable to depict one thousand mountains, say, to create an effect of infinity. One of the most common techniques, usually employed in conjunction with "aerial perspective", is to let the outlines of ridges run, intermittently perhaps, to be cut short in the course, as it were, by the confines of the frame, while the momentum of these dynamic lines is expected to carry on to evoke an unlimited expanse that can only be seen in the mind, an effect that can be illustrated by Huang Quan's Autumn Tranquillity on a Shu River (Appendix 1). In light of this, both "thousand" and "mountains" are used to furnish a pictorial space of the infinite.

The "birds flying" conveys the only dynamic image in the couplet, or even in the whole poem. It evokes something animate in the real world that the eye could follow, not because of curves as in the case of mountain ridges, but because of its physical change of position. If the mention of the bird has brought to the reader's mind some liveliness of creatures, it is given just to be taken away, to be wiped out, as it were, at the end of the line where the text is waiting with a highly charged word that judges as well as reports - jue "vanish".

\section{Line 2}

The second line mirrors the sequential pattern of the first, but it is pertinent to a different, i.e. human, world. The word for the man-made items of roads and paths, "ten thousand footpaths", though less cliched than the "thousands of mountains" above, works hand in hand with the first line in achieving a global perspective. When visualized, the element of a path conveys a convenient image with a distinct perceptual gradient of size that would give the picture a sense of depth, as would their curvy courses invite the eye to follow. Traces of humanity along the footpaths should be visible under normal weather conditions, and the imagery of the roads and paths bustling with travellers, if actualized in ink, may appear to be quite close to the road-scene depicted in the painting Travelling Along a Snowy Stream in the Mountain by a painter surnamed $\mathrm{Zhu}$ in the Song dynasty (Appendix II).

Visually, such presentation of details creates an independent spatial system within the whole picture. But even more important is the temporal direction the imagery indicates. The gradual presence in the wilderness is the corollary of a process of treading or construction, and the traces they bear are reminiscent of activities occurring in the past or 
in the present. Since roads are built for travelling, they strongly suggests humanity. Yet humanity, similar to the flight of the birds, is given to be withdrawn from the reader's mind, in the same brutal and rough manner - mie "annihilated".

Thus in the first couplet of the poem, twice has life been summoned only to be denied - all the animation (the flight of the bird and the voyage of man) seems to have been obliterated by a force that is not yet identified in the text. And twice has this act of obliteration been placed in the end focus of the syntactic structure of information jue and mie, both meaning "dying out" or "extermination".

\section{Line 3}

After scanning the whole universe - looking up to search in the sky over the mountains and find no living creatures, looking down to search along the paths and find none either - at the beginning of this line, the text picks up a visual focus on the river, the would-be centrepiece in a pictorial realization : a boat. The image, by the consistency of its shape, would perceptually detach itself from the rather haphazard environment presented in the first couplet (see Arnheim, 1971, p. 71 for the visual effect of a consistent shape). If our mental camera has been scanning the landscape of the first half of the poem, then it starts to zoom in now, as the line moves from the boat to a palm-bark cape, a bamboo or palmbark hat, before fixing on an old man. Addressing the sense of touch, of "texture", is another visual enhancer besides the consistency of shape to this zooming-in effect (see Amheim, 1971, p. 215; Chinese painters also believe that to appreciate the power concealed in the spatial relationships of the components of a landscape, one has to view the scene from afar, and to grasp the texture one has to look at it closely. This being the case, the naming of a textural characteristic would suggest the perception of a "close look"). A palm-bark cape is a dark brown garment made of palm bark sewn together, commonly worn by Chinese farmers or fishermen to protect themselves from bad weather. To name the palm-bark therefore conjures not only colour but also the textural detail of its fibre.

The word wen, that is, the "old-man", is also worth noting for its perceptual effect and cognitive impact. The age of a person in an ample cape can only be guessed at from their face (or perhaps their hands). The word, in this context, effects a close-up shot of the face or the hands wrinkled and weathered with age. With the series of images 
unfolding in such a way, the image of the old man is presented at the end of the line as the focus of the poem both as a picture and a text.

Words such as "lone", "lonely", "alone" and "solitary", which are frequently seen in Chinese poetry as $g u$ or $d u$, play a magical role as well in mental cognition resulting from visual perception. They are by nature words for focussing. This is not simply because they name a state of singularity that is numerically in a different category from plurality. It is more significant to note that they imply the conclusion of an assessment of an entity's existence in space (and time), and thus articulate the unity of its being. In real-life perception, one cannot arrive at this judgemental conclusion before the completion of a panoramic survey. This is true as well in viewing a painting. Such visual scanning, however, is physically impossible in the reading of a poem. But the experience still holds true in that the moment the word such as "lone" meets the eye, we would cognitively trust it to be the conclusion of a perceptual observation or experience, and as such we are given to accept it vicariously as our own before proceeding with the reading. In the text, the naming of an image's status, as such, singles it out in a peculiar relation to its environment, that is, to what is brought forth in the co-texts. And this is how we, up to this point in the text, can perceive the material relationship between the old man, through his (fishing) appurtenances, and the environment created in the previous couplet.

\section{Line 4}

Solitude is reiterated tautologically at the beginning of this last line of the poem : $d u$. The two Chinese synonyms referring to solitude, i.e., $g u$ and $d u$, translated as "lonely" and "alone" in English; thus they invite awareness of the state of affairs from two different perspectives and are therefore not entirely interchangeable. The difference can be amplified for easier distinction by compounding the two respectively with the word $l i$, literally meaning "stand". Namely, guli : "standing by oneself without the support supposed to be needed" - a state of isolation; and duli: "standing by oneself without the need for support" - a state of independence. As such, if the previous $g u$ serves to direct a panoramic scanning onto a particular image, i.e. the boat, to begin a line that zooms in, then this assertive $d u$ touches off a line that zooms out to take in the scene where a confrontation between the old man and, as it turns out, the snow is taking place. 
The confrontation takes place in the form of diao "fishing" or rather "angling", which in many literary traditions is a profoundly symbolic act of gladiatorial contest on physical and/or spiritual planes. The act in the poem, however, is not accompanied by overt actions or heroic grandeur as seen in sea fishing of a, say, Hemingwayan or Melvillian style. Indeed, traditional Chinese art and literature demonstrates little enthusiasm for sea fishing. What it tries to bring out is more the spiritual power that lies underneath the apparent inactivity of angling. A look into the word's semantic implications would therefore seem to be in order. In Chinese diao means more than just "catching fish". In a strict piscatorial sense, it denotes fishing with a fishing rod, as "angling" in English. But, as it stands, the word does not necessarily indicate such fishing as a pastime, hobby, sport, recreation or even competition as non-industrial fishing has tended to be regarded in the West in the last few centuries. Nor does it sound as trivial or casual as trying to catch fish with naked hands as the word guddling might have suggested. What is most significant in its semantic value for the interpretation of the poem lies in its potential philosophical overtone, originating in a legendary figure in Chinese history named Jiang Tai Gong, who was seen by the king angling without hook and bait, an ancient anecdote made known to almost every Chinese speaker via the proverb - "Only the most willing would rise to Jiang Tai Gong's line" - a point that has been noted by the translator of version 2 in Appendix 5. Thus, in Chinese culture, the unworldly primitivism of angling, given the right situation, can be indicative of a philosophical thoughtfulness, a paradigm of the waiting in Heideggerian meditative thinking, in which "we leave open what we are waiting for" ("Conversation on a Country Path", in Heidegger, 1966, p. 68), that is, "waiting upon" without willing as against "waiting for" with an intention or purpose.

Visually, a picture of fishing as angling normally includes a line from the tip of the rod down into the water, which will lead the eyes normally, from the figure of the angler to the rod and eventually to the water, the river. This is what the word diao in the poem would suggest to the mind in its cognitive process - from the old man angling, through a thin fishing line, to the river, the earth. A similar effect can be felt in examining the painting, Angling Alone on a Cold River, by Ma Yuan (Appendix 3). In reading the poem, before the eye and mind reach the river, the text gives it through modification as "cold", a quality resulting from the impact of the weather that produces the snow, an image called forth to substantiate the power of heaven. 
Not until the last word does the poem name the brutal force that has driven the bird from the sky and man from the road, the force that has made the old man stand out so lonely, and so singularly.

\section{The whole text as a mental-picture : with an advised "misreading"}

Without naming any sound-giving element such as the wind, the imagination-evoking world of the poem appears to be a silent one. Its colour scheme, with the white of the snow setting off the dark brown of the palm-bark cape in the middle of the river, presents a sharp yet simple contrast when visualized. The space contains no visible movement either, no flying of birds or trudging of man, not even the flurrying or drifting of snow. The static mental picture produced by the poem seems to be stifling monotonous and lifeless.

Yet in the picture, supposedly close to the centre of the frame, is that fishing line stretching from the rod down into the water, which can be made visible since the mind, as the art at that stage of development, is not fettered by perspective accuracy. The fishing line thus appears similar to the one in Ma Yuan's painting of a lone angler (Appendix 3), in which it is more evident as it seems disproportionately "thick" especially against the fishing rod which looks peculiarly short. This is a crucial line that links man to heaven and earth, and to other living beings. Centered on this line, there is a complex of shapes. The shape-element most expressly given in the text is mountains and probably rocks through which the footpaths thread on. Ranges of mountains, as well as clusters of rocks, with their wedge shapes pointing upwards, are deemed in visual art to be of a dynamic quality, reminiscent of the physical forces that have created them (Arnheim, 1971 , pp. 404, 414), as what we can see in the highly dynamic image of waves. On the other hand, because of their size, substance, and above all their broad base, mountains are conceptually regarded as a symbol of stability and perpetuity. With mountains and rocks as the major component, the environment, motionless as it seems, is itself full of internal tension between the two basic qualities of the imagery of mountain and rock.

In visual art, it is believed that the intensity of shape has a psychological effect that is more masculine in comparison with that of colour, and appealing more to the intellect than to emotion, as noted in Arnheim (1971, pp. 324-26), that is, 
[...] it is probably the expressive qualities (of color, but also of shape) that spontaneously affect the passively receiving mind, whereas the tectonic structure of pattern (characteristic of shape, but found also in color) concerns the actively organizing mind.

In light of this, it becomes obvious that, with emphasis on shape rather than colour, the first couplet of the poem as a verbal painting of a wintry scene can have more impact on the intellectually thinking mind than on the emotional feeling heart. In the composition of a traditional Chinese painting of landscape (i.e., "mountain and river"), a fishing boat or rod is regarded as a classic image to "make man's meaning full", and fishing or angling is put into the scenery to bring forth the spirit of the water (Guo Xi in ZHSJ, 1981, pp. 13, 16). What can this "man's meaning" or "water's spirit" be, then, in individual paintings? Its interpretation depends on the ambience of the environment projected in the painting as a whole. And with the environment given as such in the verbal painting of the poem River Snow, the aged angler can have no idyll to bring forth as one angling in the mild, quiet, and cultivated scenery of, say, rural England could have. Probably this explains why the poem has aroused in one of our translators a surreal feeling that its language "is an embodiment of steeliness", and that the poet has written, as it were, "with a bronzed stiletto" (Wu, 1972, p. 162). Instead of being an idyll, the hostile bleakness of the scene has bestowed on the angler a heroism of defiance against the brutality of elements and destiny.

As we have noted above, the confrontation between the man and the environment takes the form of fishing, which in the poem is presented in its most elementary, simplistic and primitive state of angling. Such primitivity, i.e., angling divested of its technical details, touches upon the nakedness of human existence between heaven and earth, as seen in Ma Yuan's painting, to launch readers/viewers into a meditative thinking about the fundamental aspects of man's being mortal, vis-à-vis the eternal vulnerability and lonesome tenacity of human existence as distilled in the solitary angling figure. Any presentation that shifts the focus from man angling towards the piscatorial technicality or pragmatic purposefulness of fishing would bring too much to the foreground of the worldly actuality of the activity to encourage or sustain meditative thinking.

This is what we have found in Ma Lin's painting of Angling Alone on a Cold River (Appendix 4 (A)) in comparison with Ma 
Yuan's work of the same title. In Ma Lin's, "angling" should read "netting", as the fisherman is seen fishing with a rather sophisticated netting device, which includes a sizable drop net hung underwater from the tip of a pole extended from the fishing platform. The whole net trap is connected to that crane-like mechanism above, to ensure that the net can be hoisted with carefully controlled speed out of water at a certain interval, to be examined for any catch (Appendix 4 (B)). Highlighting the instrument's level of sophistication, as capturing the triumphant moment of a hooked fish being pulled on board, tends to draw, unnecessarily in this case, the viewer's attention to the worldly cunningness or materialist purposefulness of fishing, blocking out the mental space that could have been kept open for a world viewed anew through a more meditative presentation of angling. Express concern with objective complexity in Ma Lin's painting has worked to turn the man into an image of a Trade Fisherman rather than one of a philosophical angler who is open to what he "waits upon". Compared with Ma Yuan's work, the painting would set the viewer wondering more about the security of the man's evening repast than speculating upon the insecurity of man's existence, so to speak.

Kao and Mei have proposed a distinction between the primarily perceptual imagistic pole and the primarily conceptual propositional pole in the language of Tang Regulated Verse of Chinese classical poetry to which this poem belongs; the authors also observe that the final couplet (or line) tends to be propositional language and may perform the unifying function that ties the previous, more imagistic lines into "an organic whole" (Kao and Mei, 1971, pp. 5861). This, by and large, is the mode in which the text of River Snow has progressed. As to this concluding line, the contending forces, i.e., the old man and the snow, are brought together in a confrontation through the meditative act of angling. In this last line that unifies the entire poem, it is interesting to note that the verb diao "angling" is followed immediately by the noun phrase "cold river snow", as a verb would by an object.

For both grammatical correctness and objective truthfulness, the last two images in the noun phrase, i.e., the (cold) river and the snow, have conventionally been interpreted as an adverbial compound denoting the location and the environment where the fishing is being carried out. The adherence to grammatical correctness and objective truthfulness is evident in the translations listed in Appendix 5, although the translator of version 2 has mildly questioned the conventional 
reading and ventured a tentative alternative reading in one of his notes to the translation: "fishing for winter snow". Admittedly, it is arguable that the world truth would have been spelt out by the poet as, e.g., fishing on the river and in the snow, had it been a line in prose where little length regulation is imposed on each sentence; and the English translations are thus justified since English grammar requires a preposition in this connection anyway. In the Chinese poetic text, however, the interaction between the highly regulated formal requirements of the genre and what the poet had to say at the moment has led to a verb-noun combination, namely, "angling river snow", which has created an ambiguity that opens to multiple readings.

In reading the Chinese text, it is the reader's responsibility to mentally supply the missing preposition to justify their readings. And with different prepositions there will come to mind different pictures of the scene. For instance, with "fishing in the snow" the picture would be a matter-of-fact one truthful to the objective world; and with "fishing against the [background or brutality of] snow" the picture, still truthful to the objective world, would shift its focus from the material to the spiritual, having the old man standing out perhaps with a touch of martyrdom.

What makes most of the English translations in Appendix 5 less cognitively effective than their Chinese source text, among other things, is that they have opted to insert the preposition in. This narrows the text down to one rendering, the most prosaic, which, by being truthful to the objective world, generates a neat and pretty picture of fishing, which, in an English-speaking culture, may appear little different from an ordinary scene of winter fishing, or hunting. While the translations represent the conclusion of a process of calculation that has worked out the spatial accuracy of the fishing, the Chinese text represents the stimulus of a process of thinking, i.e. as a source of inspiration conducive to multiple possibilities of poetic meditative thinking, if one is so inclined to explore them. Such listening and responding to the text as a poem, according to Heidegger, is "a vigilance that issues from a long and ever-renewed thoughtful deliberateness, which heeds the directive that lies in the manner in which Being makes its appeal" (Heidegger, 1971, p. 184, italics added).

Meditative thinking in the guise of vigilance enriches one's reading experience because the manner in which the being of the poetic text makes its appeal provides cognitive space for enriched 
interpretations. As in this case, the text of River Snow inspires not only mental pictures of angling in or against snow, but also one of "angling the snow", by advisedly misreading the dual nature of diao "angling" as both a transitive and intransitive verb, and the absence of a preposition to explicate the relation between the verb and the following noun phrase.

The mendacity or poetic ambiguity in "angling the snow", as "one thousand mountains" and "ten thousand footpaths", can only be conceived on a mental level. It defies scientific calculation and pictorial representation. It remains exclusive to the poetic rather than the scientific. In such a virtual painting by a meditative mind, a new world stays where the snow, by being placed in a syntactic position of object, appears to be an "anglable" object (as against the agent) in the power transitivity of angling. The snow, with all its overbearing force that has cleansed both animal and human worlds, is thus subdued, being on the receiving end of an interplay of spiritual power with the old man, who is waiting with a fisherman's patience. And patience, in Heidegger's words, "nurtures magnanimity" ("The Thinker as Poet", Heidegger, 1971, p. 9).

The process of apotheosis is complete with the old angler being treated as someone angling with patience for something more than a fish. In such angling he is consecrated with a divinity that transcends his mortality. As the distance from worldliness has distinguished Ma Yuan's painting from Ma Lin's, this closeness to transcendental divinity distinguishes the Chinese text from its English translations in its inspirational and critical nature.

\section{Some concluding remarks}

Our discussion so far attempts to illustrate, through an intensive analysis of the poem Snow River, how a poem thinks, or rather, how its textual formulation can set a reader thinking, as a poem qua poem thinks in the way its language makes the reader think. In other words, it is the poetic way of thinking that a poem inspires that determines the poem's being a poem. A Chinese landscape poem that thinks as well as portrays, if viewed in this light, is comparable in nature to the jug Heidegger describes (see "The Thing" and its "Epilogue", in Heidegger, 1971, pp. 165-186) to reveal the thingness of things; and the poetic meditative thinking a poem inspires becomes its "gift of the outpouring". The poetic meditative thinking from such a jug of a poem, 
a textual receptacle shaped by the imagistic and propositional language in which the fourfold of earth and sky, divinities and mortals stays to world the world, is what Heidegger would call the poem's "authentic gift" (Heidegger, 1971, p. 173) of its outpouring, for it is not mere drink to refresh mortals' sensual leisure but also libation for the immortal gods, the spiritual of humanity.

For a poem to inspire meditative thinking, it has to be viewed as a world "thinged" by the images it has called into being; and it has to be listened to and responded to as its language appeals, as in this appeal the textual "holding void" of the poem, its being, gives in a far richer way than the way it takes and keeps. On the other hand, for one to remain open to such inspiration of meditative thinking, one has to adopt a meditative mode of thinking in the first place. Such a mode of thinking is "the vigilance of mortals", without which things will not "appear as things", and the first step towards which "is the step back from the thinking that merely represents - that is, explains - to the thinking that responds and recalls" (Heidegger, 1971, p. 181).

To translate a poem as a poem therefore requests one to read its being a poem, that is, to read its text as a cognitive process in which it offers its poetry, becoming a poem. It means to approach it through meditative thinking, and in such a mode of thinking (then reading and translating) to remain open and free to the meditative thinking it inspires as gift - by stepping back from the calculative mode of thinking that seeks to represent objects in their material accuracy. To translate a poem that inspires meditative thinking is, in essence, to produce a target text that will set the reader thinking, in a similar, meditative way. And in this sense poetic translating, in particular, is a process that is never finished. It is rather like the old man in the poem fishing - for and remaining open to something beyond a fish :

A thousand mountains no birds flying

Ten thousand paths devoid of human trace

A lone boat, a bark-caped old man -

Alone, he angles a cold river of snow

City University of Hong Kong 


\section{References}

ARNHEIM, Rudolf (1971 [1954]). Art and Visual Perception: a Psychology of the Creative Eye. Berkeley, etc., U. of California Press.

DENG, Qiaobin (1993). Yousheng Hua yu Wusheng Shi [Speaking Picture and Mute Poetry]. Shanghai, Shanghai Shehui Kexue Chubanshe.

HEIDEGGER, Martin (1966). Discourse on Thinking. John M. Anderson and E. Hans Freund tr. New York, etc., Harper Colophon Books.

- (1971). Poetry, Language, Thought. Albert Hofstadter tr. New York, etc., Harper Colophon Books.

JENYNS, Soame (Tr.) (1944). A Further Selection from the Three Hundred Poems of the T'ang Dynasty. London, John Murray.

KAO and MEI (1971). "Syntax, Diction, and Imagery in T'ang Poetry". Harvard Journal of Asiatic Studies. 31, pp. 49-136.

LANG, Shaojun et al. (eds.), (1988). Zhongguo Shu Hua Jianshang Cidian (An Anthology for Appreciation of Chinese Painting and Calligraphy). Beijing, Zhongguo Qingnian Chubanshe.

WEN, Shu (ed.) (1989). Shici Yingyi Xuan [Selected Poems and Lyrics in English Translation]. Beijing, Waiyu Jiaoxue yu Yanjiu Chubanshe.

WU, John C.H. (1972). The Four Seasons of T'ang Poetry. Rutland \& Tokyo, Charles E. Tuttle.

XU, Fang (1983). Tangshi Jinyi [A Translation of Tang Poems in Modern Chinese]. Beijing, Renmin Ribao Chubanshe.

XU, Yuanzhong et al. (1988). 300 Tang Poems : A New Translation. Beijing \& Hong Kong, Zhongguo Duiwai Fanyi Chuban Gongsi \& Shangwu Yinshuguan.

ZENG, Jingchu (1989). Zhongguo Shi Hua [Chinese Poetry and Painting]. Beijing, Guoji Wenhua Chuban Gongsi. 
ZHOU, Yukai (1992). Zhongguo Chanzong yu Shige [Chinese Zen and Poetry]. Shanghai, Shanghai Renmin Chubanshe.

ZHSJ (publ.) (1981). Zhongguo Meixueshi Ziliao Xuanbian II [History of Chinese Aesthetics, Selected Data II]. Compiled by the Aesthetics Programme of the Department of Philosophy. Peking U. Beijing, Zhonghua Shuju.

\section{Some Sources of the Appendices}

Tang Song Yuan Ming Minghua Daguan (1976) [A Collection of Famous Chinese Paintings: Tang, Sung, Yuan \& Ming Dynasties]. Taiwan, Chengwen Chubanshe.

Liang Song Minghua Ce (1963) [A Collection of Famous Chinese Paintings of the North and South Song Dynasties]. Beijing, Wenwu Chubanshe.

ABSTRACT : Perception and Cognition in Translating Chinese Landscape Poetry : A Case Study of Liu Zongyuan's Poem River Snow - The article, based on the Heideggerian dichotomy of calculative versus meditative thinking and with reference to Arnheim's psychology of visual art, argues that a poem thinks in the way it makes the reader think, and it is the poetic (meditative) way of thinking that a poem inspires that determines the poem's being a poem. Through an intensive case study of a classical Chinese poem, it tries to illustrate how a poem's textual formulation can set a reader thinking. It follows that to translate a poem as a poem, the translator must approach the source text with the mind open and released to the meditative thinking it inspires as gift - by stepping back from calculative thinking which strives to represent objects in their material accuracy, so as to produce a target text that will set the target reader thinking in a similar, meditative way.

RÉSUMÉ : La perception et la cognition dans les traductions de la poésie chinoise du paysage : cas du poème River Snow de Liu Zongyuan - Cet article, basé sur la dichotomie heideggerienne de la pensée calculative par opposition à la pensée méditative et sur la psychologie des arts visuels de Arnheim, propose que la pensée d'un poème est celle d'un lecteur et que c'est la méditation inspirée par le poème qui détermine sa vraie nature. Par le biais de l'étude d'un poème classique chinois, nous tenterons de démontrer comment la formulation textuelle d"un poème oriente la pensée du lecteur. Ainsi pour traduire 
le caractère poétique d'un poème, le traducteur doit aborder le texte de départ l'esprit "vide» en se laissant imprégner par la pensée méditative offerte par le poème, c'est-à-dire en refusant la pensée calculative qui tente de représenter les objets dans leur matérialité, afin de produire un texte en langue d'arrivée qui provoquera aussi chez le lecteur une pensée méditative.

Chunshen Zhu, Department of Chinese, Translation and Linguistics, University of Hong Kong, Tat Chee Avenue, Kowloon, Hong Kong.

E-Mail : CTZHU@cityu.edu.hk 


\section{Appendix 1}

Autumn Tranquillity on a Shu River

By Huang Quan of the period of Five Dynasties (907-969 A.D.)

From Tang Song Yuan Ming Minghua Daguan.

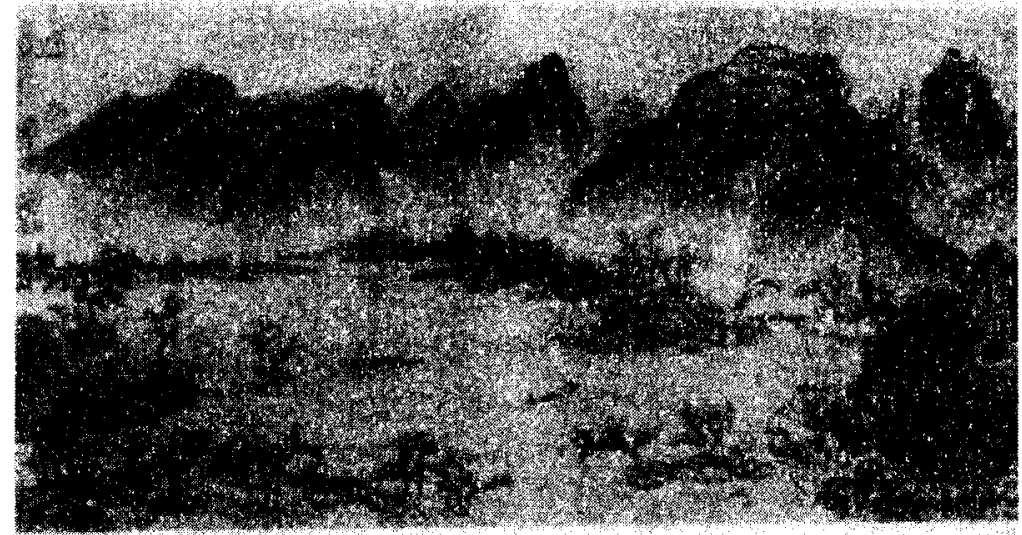

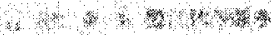

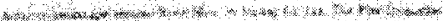

48 


\section{Appendix 2}

Travelling Along a Snowy Stream in the Mountain

By Zhu? of the Song dynasty (960-1279 A.D.)

From Liang Song Minghua Ce.

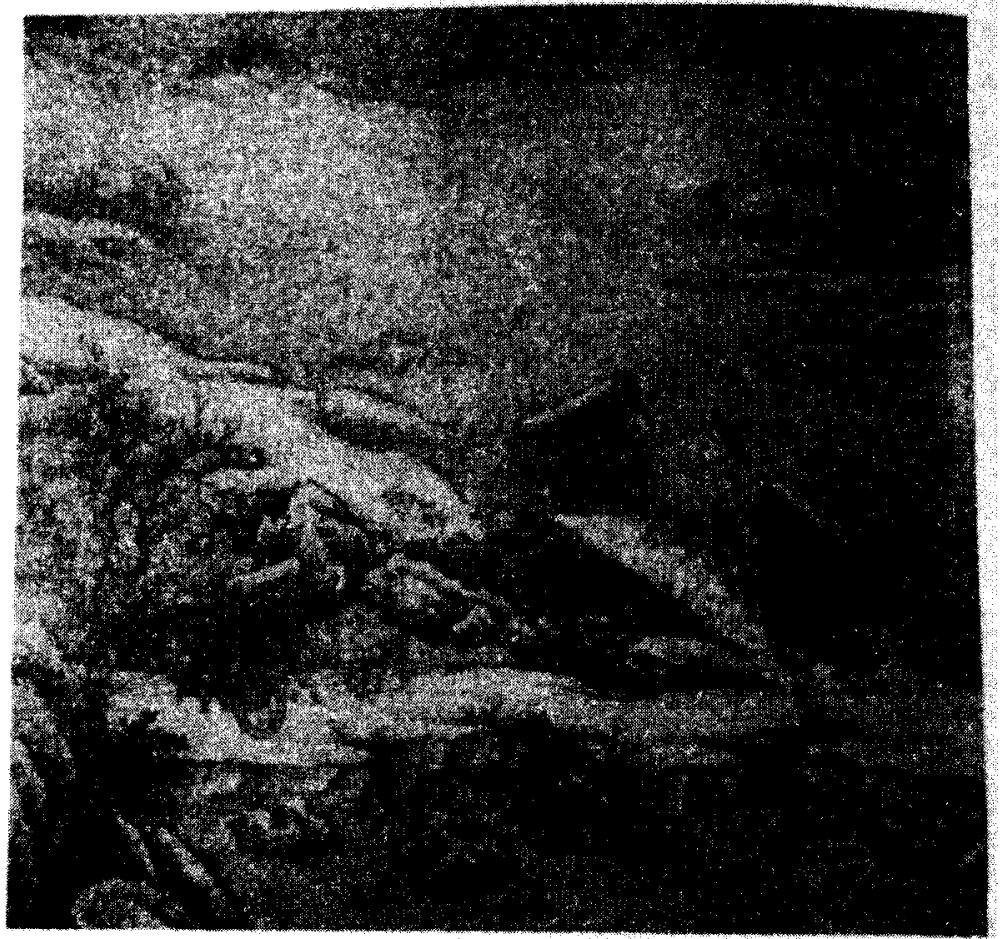




\section{Appendix 3 Angling Alone on a Cold River \\ By Ma Yuan of the Song dynasty (960-1279 A.D.) From Zeng $1989: 98$.}

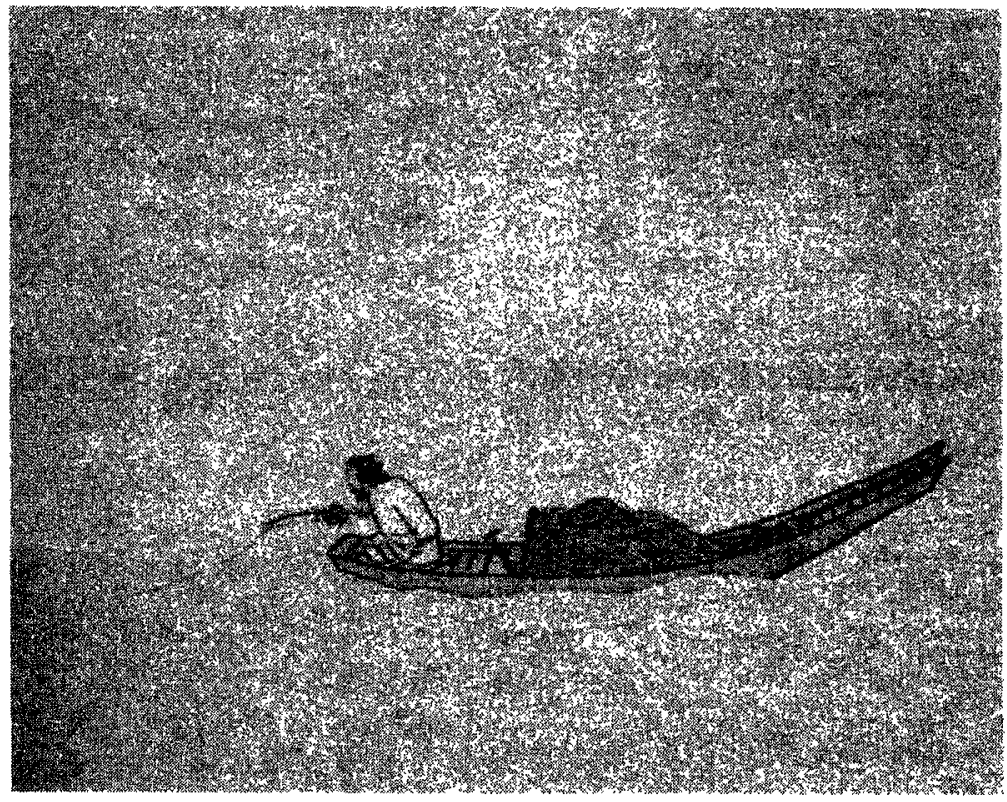




\section{Appendix 4}

Angling Alone on a Cold River

By Ma Lin of the Song dynasty (960-1279 A.D.)

From Tang Song Yuan Ming Minghua Daguan.

(A)

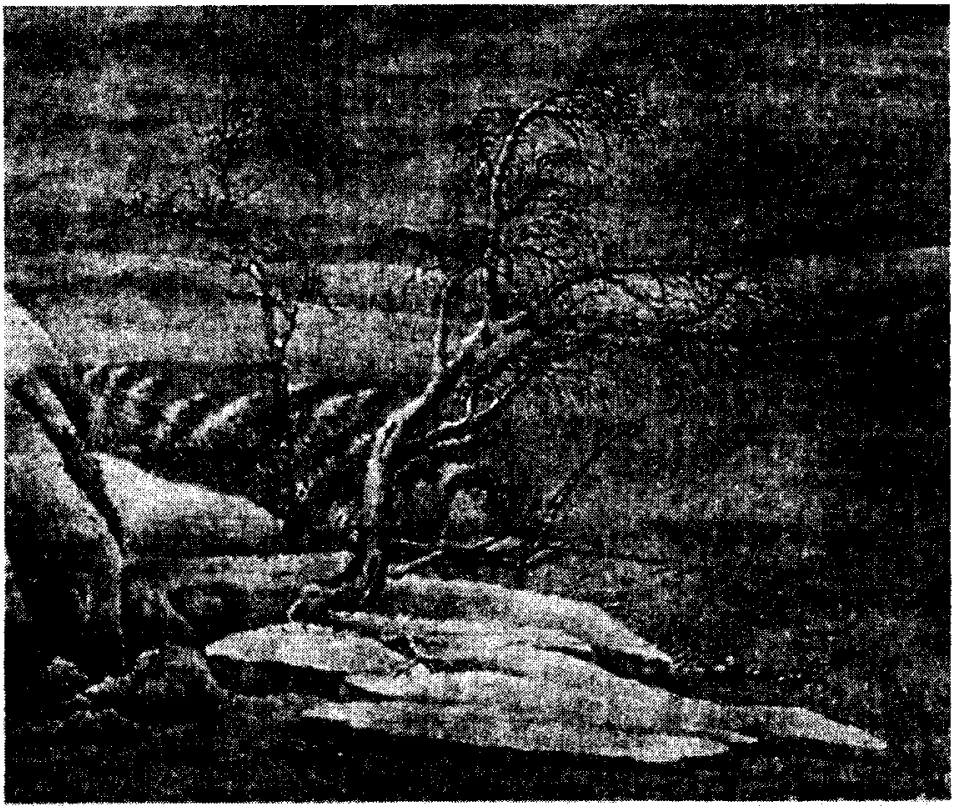

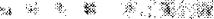

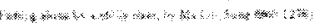




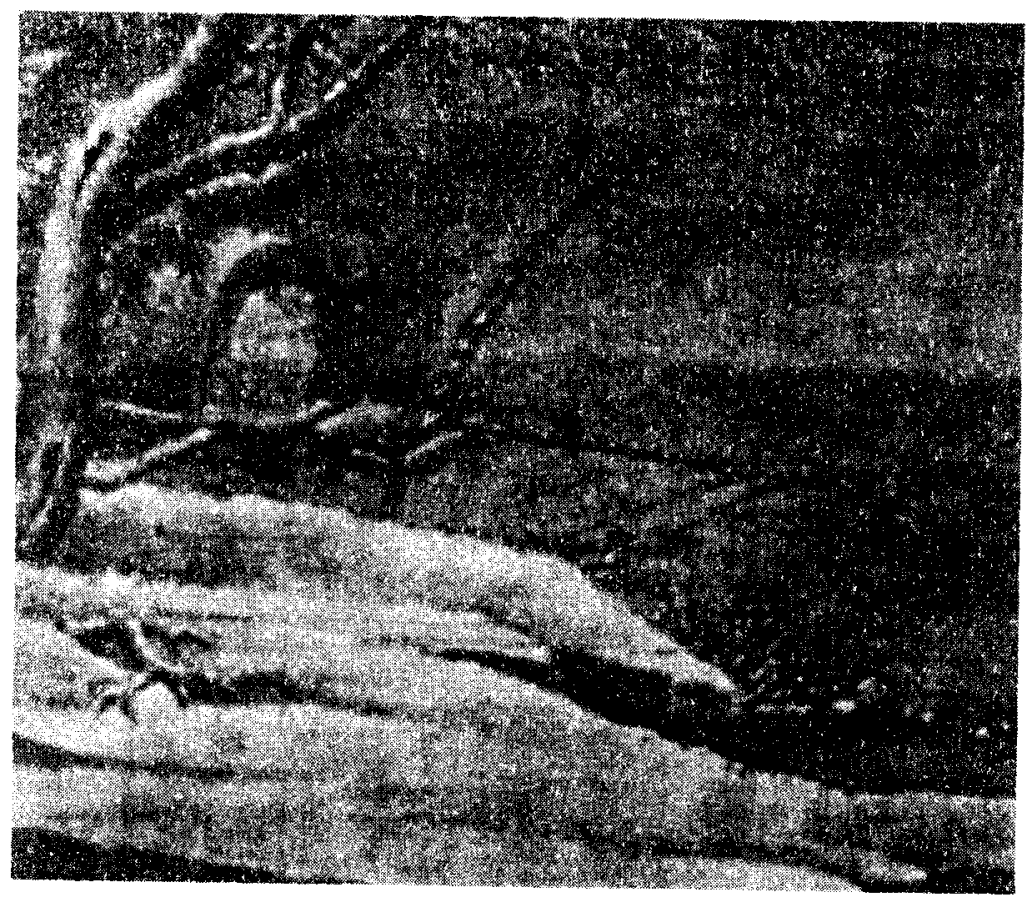




\section{Appendix 5}

\section{Translations}

\section{River Snow}

A hundred mountains and no bird,

A thousand paths without a footprint;

A little boat, a bamboo cloak,

An old man fishing in the cold river-snow.

By W. Bynner (in Wen $1989: 162$ )

\section{Snow on the River*}

On a thousand hills all birds life is cut off,

On ten thousand paths there is no trace of human footsteps;

In a lonely boat the old man with the bamboo hat and cape

Sits by himself fishing the river in the winter snow.**

Translator's notes :

* The author writes this after he had been sacked from his official job and found the world cold and bleak.

** ? "Fishing for winter snow." If he was a Buddhist philosopher he would fish without a hook.

By Soame Jenyns (in Jenyns 1944 : 78)

\section{3. [River Snow]}

Myriad mountains - not a bird flying.

Endless roads - not a trace of men.

Only an old fisherman in a lonely boat, Angling silently in the river covered with snow.

$$
\text { By John C. H. Wu (in Wu } 1972: 161-162 \text { ) }
$$

\section{River Snow}

From a thousand hills, bird flights have vanished;

on ten thousand paths, human traces wiped out :

lone boat, an old man in straw cape and hat,

fishing alone in the cold river snow.

By Burton Watson (in Wen 1989 : 163)

\section{Fishing in Snow}

From hill to hill no bird in flight;

From path to path no man in sight.

A straw-cloak'd man in a boat, lo! 
Fishing on river clad in snow.

By X.Y.Z. (in Xu et al. $1988: 305$ )

\section{6. [River Snow]}

Among the mountains

no longer any birds to be seen,

Along all the footpaths

not a trace of travellers.

At this time

Only an old fisherman,

Still rowing a small boat

Wrapped in a palm - bark cape, wearing a bamboo hat

Is all by himself fishing in the whirling snow on the cold river.

[Translated into English from]

$X u$ Fang's modern Chinese version (in Xu

$1983: 205-206$ ) 